\title{
PENERAPAN KONSEP TRIPLE BOTTOM LINE ACCOUNTING DI DESA WISATA PELAGA (STUDI KASUS PADA KELOMPOK USAHA TANI ASPARAGUS)
}

\author{
I Gusti Bagus Ngurah Panji Putra* dan Gde Deny Larasdiputra \\ Fakultas Ekonomi dan Bisnis, Universitas Warmadewa, Denpasar-Bali, Indonesia \\ *E-mail: ngurahpanji.putra@gmail.com
}

DiPublikasi: 01/01/2020

http://dx.doi.org/10.22225/kr.11.2.1419.129-136

\begin{abstract}
The purpose of this research is to examine the application of the TBLA concept in Pelaga Tourism Village, with the asparagus farming group as the research subject. This study uses a survey method and all asparagus farmer groups are used as research respondents. The data collection techniques used are interview techniques and non-participant observation. The data obtained will be analyzed using qualitative descriptive analysis techniques. The results of this study are expected to be able to contribute ideas to related parties in this case is the asparagus farming group in Pelaga Tourism Village and Mertanadi Farmers Cooperative regarding the implementation of the TBLA concept in their business activities. The translation of the three pillars of the Triple Bottom Line Accounting concept of planets, people, and profits has been translated into statement points on the questionnaire instrument. Based on the discussion of the results that have been described above both quantitatively and qualitatively, it can be concluded that the application of the triple bottom line accounting concept in Pelaga Tourism Village (case study in the asparagus farming group) in general can be concluded to have gone well.
\end{abstract}

Keywords: Triple Bottom Line Accounting, Asparagus Farmers Group

\begin{abstract}
Abstrak
Tujuan dilakukannya penelitian ini adalah untuk menguji penerapan konsep TBLA di Desa Wisata Pelaga, dengan kelompok usaha tani asparagus sebagai subjek penelitiannya. Penelitian ini menggunakan metode survey dan seluruh kelompok tani asparagus digunakan sebagai responden penelitian. Adapun teknik pengumpulan data yang digunakan adalah teknik wawancara dan observasi non partisipan. Data yang diperoleh akan dianalisis menggunakan teknik analisis deskriptif kualitatif. Hasil dari penelitian ini diharapkan mampu memberikan sumbangan pemikiran kepada pihak terkait dalam hal ini adalah kelompok usaha tani asparagus di Desa Wisata Pelaga serta Koperasi Tani Mertanadi terkait implementasi konsep TBLA dalam aktivitas bisnis mereka. Penjabaran ketiga pilar dari konsep Triple Bottom Line Accounting yakni planet, people, dan profit telah dijabarkan menjadi poin-poin pernyataan pada instrumen kuesioner. berdasarkan pembahasan hasil yang telah dipaparkan diatas baik secara kuantitatif maupun kualitatif, dapat disimpulkan bahwa penerapan konsep triple bottom line accounting di desa wisata pelaga (studi kasus pada kelompok usaha tani asparagus) secara umum dapat disimpulkan telah berjalan dengan baik.
\end{abstract}

Kata Kunci: Triple Bottom Line Accounting, Kelompok Usaha Tani Asparagus

\section{PENDAhULUAN}

Kegiatan bisnis jika dianalogikan bagaikan pedang bermata dua. Di satu sisi mampu menyediakan lapangan kerja bagi masyarakat sekitar dan meningkatkan Pendapatan Asli Daerah (PAD). Sementara di sisi lain, tak jarang eksploitasi alam secara massif demi ambisi mengejar profit semata justru dapat berdampak negatif terhadap lingkungan. Seperti contoh kasus yang dikutip dari (Nasional kompas, 2017), dimana terjadi penambangan karst yang dilakukan oleh PT. Semen Indonesia yang memiliki dampak merusak bagi keberadaan sumber air di bawah Pegunungan Kendeng.
Berdasarkan hasil kajian dan pemantauan Komnas HAM sejak Juni 2015 hingga Agustus 2016, terdapat dampak negatif atas keberadaan pabrik semen terhadap hak atas kesehatan, hak atas lingkungan hidup, dan hak atas air. Permasalahan lingkungan ini menimbulkan desakan dari masyarakat khususnya para petani Kendeng kepada Pemerintah, dalam hal ini Presiden Jokowi. Jika hal ini dibiarkan berlarutlarut, maka akan berdampak negatif terhadap keberlangsungan usaha perusahaan bersangkutan.

Fenomena-fenomena semacam ini dewasa ini mulai disadari urgensinya, dan mendapat respon yang baik dari korporasi-korporasi besar baik di dalam maupun di luar negeri. Dikutip dari 
(Swa.co.id, 2019) beberapa usaha bisnis yakni Burger King, Unilever, Nestle dan Kraft Foods menghentikan kerjasama dengan Grup Sinar Mas sebagai produsen dan pemasok bahan baku minyak kelapa sawit bagi perusahaan. Hal tersebut dikarenakan adanya dugaan perusakan hutan tropis yang membahayakan kehidupan satwa, dan mengurangi kemampuan penyerapan karbon dioksida yang menjadi salah satu penyebab utama global warming. Berita serupa datang dari luar negeri, dimana salah satu produsen pakaian dan sepatu outdoor yaitu The Timberland Company menerima protes via e-mail dari 65 (enam puluh lima) ribu aktivis dan pelanggan yang marah akibat tindakan perusahan yang membeli material produk dari hasil penebangan hutan secara ilegal di Hutan Amazon.

Disadari atau tidak, berbagai upaya yang dilakukan oleh korporasi tersebut merupakan bentuk implementasi green economy. Konsep green economy (ekonomi hijau) ini muncul sebagai solusi atas paradoks antara kegiatan bisnis dan kelestarian alam. (Lako, 2015) menyatakan bahwa konsep green economy diciptakan sebagai alat untuk mencapai pembangunan yang berkelanjutan, mampu meningkatkan efisiensi dalam penggunaan sumber daya alam, serta mendorong pola produksi yang ramah lingkungan. Secara singkat ekonomi hijau didefinisikan sebagai perekonomian yang rendah karbon dan polusi, efisien dalam penggunaan sumber daya alam, serta mencegah kerusakan lingkungan.

Konsep green economy ini lebih lanjut dijabarkan dalam konsep Triple Bottom Line Accounting (TBLA). Triple Bottom Line Accounting menekankan bahwa kinerja perusahaan tidak hanya diukur dengan indikator keuangan, melainkan juga menggunakan indikator non keuangan. Konsep Triple Bottom Line menempatkan fokus yang konsisten dan seimbang pada nilai ekonomi, sosial, dan lingkungan pada organisasi (Alhaddi, 2015). Sesuai dengan namanya, konsep Triple Bottom Line Accounting terdiri dari tiga pilar utama atau yang lebih dikenal dengan istilah 3P yaitu planet, people, dan profit. Planet merupakan perwujudan dari bentuk kepedulian perusahaan terhadap alam dan lingkungan sekitar. (Wilson, 2015) pada penelitiannya menyatakan bahwa strategi bisnis yang memperhatikan aspek lingkungan dapat menghasilkan manfaat finansial dan sosial yang positif. Bentuk implementasi perusahaan terkait aspek lingkungan adalah implementasi program Corporate Social Responsibility (CSR). Entitas go public mulai berlomba-lomba melakukan program CSR dan bahkan merasa penting untuk memperoleh penghargaan di bidang lingkungan. Informasi terkait CSR yang telah dilakukan dan penghargaan di bidang lingkungan yang telah diperoleh umumnya akan disajikan pada annual report dan/atau website resmi perusahaan. Pengungkapan ini dirasa penting bagi para stakeholders. Khusus bagi investor, informasi ini akan menjadi sentimen positif terkait keberlangsungan (sustainability) perusahaan kedepannya.

Pilar people berkaitan dengan bentuk kepedulian perusahaan terhadap sumber daya manusia yakni tenaga kerja. Seperti misalnya tidak melakukan eksploitasi terhadap tenaga kerja di bawah umur, pemberian upah yang wajar, lingkungan kerja yang aman, jam kerja yang dapat ditoleransi, adanya sistem penghargaan bagi karyawan yang berkinerja baik, penyertaan asuransi keselamatan kerja, termasuk juga penyertaan karyawan dalam pelatihan sebagai bentuk pemberdayaan karyawan. Perusahaan sadar bahwa salah satu aset penting perusahaan merupakan karyawan. Peningkatan kualitas produk atau jasa, munculnya ide atau inovasi baru, semuanya bergantung pada kinerja karyawan. Hal itulah yang menjadi alasan utama bagi perusahaan untuk memperhatikan kesejahteraan dan keselamatan dari karyawan. Melalui peningkatan kepuasan karyawan tentu akan berdampak pada kesuksesan perusahaan.

Pilar profit berkaitan dengan kemampuan perusahaan untuk menghasilkan keuntungan. Dalam konsep TBLA, pilar profit bukan merupakan konsep parsial yang mampu berdiri sendiri, namun harus dikaitkan dengan pilar planet, dan people. Pilar profit tidak hanya sekedar mengejar keuntungan, tetapi mampu menciptakan bisnis yang adil dan beretika. Fair trade dan ethical trade merupakan salah satu contoh penerapan pilar profit dalam konsep TBLA. Pihak perusahaan bersinergi dengan masyarakat sekitar dalam upaya penyediaan bahan baku, dengan catatan harga beli harus menyesuaikan dengan fair value atau harga wajar.

Di tengah deraan tantangan global seperti kemiskinan, bencana alam, dan perubahan iklim, isu pembangunan berkelanjutan menjadi topik yang hangat dibicarakan. Dengan mengusung konsep TBLA yang merupakan bagian dari 
konsep green economy, diharapkan mampu memaksimalkan pertumbuhan perekonomian di Indonesia sebagai salah satu bentuk pembangunan berkelanjutan. Sinergi dan keselarasan antara pengentasan kemiskinan di daerah pedesaan, pelestarian lingkungan, dan pertumbungan ekonomi diwujudkan Pemerintah Indonesia dalam program One Village One Product (OVOP). Melalui program ini pemerintah berupaya untuk memberdayakan masyarakat khususnya petani melalui Usaha Mikro Kecil dan Menengah (UMKM). Secara tidak langsung, program OVOP merupakan bentuk pelestarian terhadap kekayaan setempat (local wisdom) yakni pengetahuan akan pertanian. Dikenalnya Indonesia sebagai negeri agraris merupakan bukti bahwa jati diri dari Bangsa Indonesia merupakan sektor pertanian. Melalui program OVOP ini diharapkan dapat meningkatkan atensi dan dukungan terhadap dunia pertanian yang berkelanjutan, sehingga petani tidak lagi identik dengan kemiskinan.

Berdasarkan Peraturan Bupati Badung Nomor 47 Tahun 2010 tentang Penetapan Kawasan Desa
Wisata di Kabupaten Badung, disebutkan bahwa salah satu kawasan yang menjadi desa wisata adalah Desa Pelaga. Desa ini dikenal sebagai desa pertanian yang menyajikan kawasan wisata agro yang menarik karena ekologinya yang utuh. (Wahyudin, 2016) menyatakan bahwa pembangunan berkelanjutan juga sering dijabarkan dengan perbaikan kualitas hidup dan pertumbuhan ekonomi yang disesuaikan dengan daya dukung lingkungan (potensi alam yang dimiliki).Salah satu potensi alam dari desa ini yang kemudian menjadi komoditi unggulan adalah tanaman asparagus. Dinas Koperasi, UKM, Perindustrian dan Perdagangan Kabupaten Badung mengimplementasikan program OVOP di Desa Pelaga dengan menerapkan budidaya asparagus sebagai produk sayuran unggulan hortikultura. Program ini diharapkan mampu memberikan manfaat bagi masyarakat desa melalui peningkatan taraf perekonomian masyakarat setempat. Selain itu, unsur hiburan, edukasi, pelestarian lingkungan, serta upaya konservasi alam juga menjadi fokus kegiatan ini sesuai dengan konsep ekowisata (ecotourism).

Tabel 1

Kawasan Desa Wisata yang Terletak di Wilayah Kabupaten Badung

\begin{tabular}{ccc}
\hline No & Nama Desa & Lokasi \\
\hline 1 & Desa Bongkasa Pertiwi & Banjar Karang Dalem I, Kecamatan Abiansemal \\
2 & Desa Pangsan & Banjar Sekar Mukti Pundung, Kecamatan Petang \\
3 & Desa Kerta & Kecamatan Petang \\
4 & Desa Plaga & Banjar Kiadan, Kecamatan Petang \\
5 & Desa Belok & Banjar Lawak, Kecamatan Petang \\
6 & Desa Carang Sari & Kecamatan Petang \\
7 & Desa Sangeh & Kecamatan Abiansemal \\
8 & Desa Baha & Kecamatan Mengwi \\
9 & Desa Kapal & Kecamatan Mengwi \\
10 & Desa Mengwi & Kecamatan Mengwi \\
11 & Desa Munggu & Kecamatan Mengwi \\
\hline
\end{tabular}

Sumber: Peraturan Bupati Badung Nomor 47 Tahun 2010

Alasan lain yang menjadi latar belakang peneliti tertarik melakukan penelitian terkait kelestarian lingkungan adalah diterbitkannya aturan baru oleh Pemerintah Provinsi Bali yakni Peraturan Gubernur Nomor 97 Tahun 2018 tentang Pembatasan Timbulan Sampah Plastik Sekali Pakai. Peraturan ini mengatur tentang pengurangan penggunaan plastik oleh masyarakat dan pelaku usaha bisnis. Hal ini tentu beralasan karena plastik menjadi komponen yang tidak bisa dipisahkan dari kegiatan bisnis. Mulai dari sedotan plastik, kemasan produk hingga kantong plastik menjadi hal yang kerap ditemukan dalam aktivitas bisnis. Berdasarkan hal tersebut, peneliti tertarik untuk mengetahui sejauh mana aturan ini telah diterapkan oleh pelaku usaha bisnis dalam hal ini kegiatan bisnis yang dilakukan kelompok usaha tani asparagus di Desa Pelaga. Topik penelitian terkait penerapan Triple Bottom Line Accounting masih sangat minim dilakukan di Indonesia. Sementara tingkat urgensinya sudah sangat tinggi. Hal itu yang mendasari bahwa penelitian ini penting untuk dilakukan. Adapun judul penelitian yang akan saya angkat adalah "Penerapan Konsep Triple Bottom Line Accounting Di Desa Wisata Pelaga (Studi Kasus pada Kelompok Usaha Tani Asparagus)". 


\section{TINJAUAN PUSTAKA}

\section{Ekonomi Hijau}

Ekonomi hijau adalah sistem ekonomi yang mampu meningkatkan kesejahteraan manusia dan sekaligus secara signifikan mengurangi resiko lingkungan dan kerusakan ekologi melalui efisiensi sumber daya alam, rendah karbon, dan kepedulian sosial (Ilma, 2014). Dalam ekonomi hijau, pertumbuhan pendapatan dan penciptaan lapangan kerja bersumber dari investasi pemerintah maupun swasta yang rendah polusi, efisien dalam pemakaian energi sumber daya alam, serta mampu mencegah kerusakan keanekaragaman hayati dan lingkungan (Hijauku, 2019). Konsep ekonomi hijau tidak hanya menekankan pada penilaian lingkungan secara ekonomi dan pemberian sanksi terhadap aktivitas operasional yang memiliki dampak negatif dan berpotensi merusak lingkungan, tetapi yang lebih penting adalah mampu mendorong pelaku ekonomi untuk memproduksi produk dan mengkonsumsi hal yang ramah lingkungan. Pendapatan yang dihasilkan dari penerapan konsep ekonomi hijau diharapkan mampu menjadi trigger untuk mendorong pelaku ekonomi lainnya untuk melakukan aktivitas bisnis yang lebih ramah lingkungan.

(Wilson, 2015) menyatakan bahwa strategi bisnis yang memperhatikan aspek lingkungan dapat menghasilkan manfaat finansial dan sosial yang positif. Berry dan Rondinelly (1998) dalam (S \& Arifah, 2006), berpendapat bahwa terdapat beberapa kekuatan yang mendorong perusahaan untuk memperhatikan aspek lingkungan.

\section{Triple Bottom Line Accounting}

Istilah Triple Bottom Line dipelopori oleh Elkington dalam buku Cannibals With Forks. Dalam definisinya tentang Triple Bottom Line, Elkington menggunakan istilah profit, people, dan planet sebagai tiga garis (Elkington, 1998). Triple Bottom Line Accounting menekankan bahwa kinerja perusahaan tidak hanya diukur dengan indikator keuangan, melainkan juga menggunakan indikator non keuangan. Konsep Triple Bottom Line Accounting menyediakan kerangka kerja untuk mengukur kinerja bisnis dan keberhasilan organisasi menggunakan tiga jalur, yakni bidang ekonomi, sosial, dan lingkungan (Goel, 2010)

Menurut (Foran, Lenzen, Dey, \& Bilek, 2005) konsep triple bottom line accounting secara luas dikembangkan sebagai cara dimana perusahaan dapat mewujudkan tujuan sosial yang lebih luas disamping meningkatkan nilai pemegang saham. Triple Bottom Line Accounting (TBLA) telah menjadi isu utama dan hangat dibicarakan dalam berbagai kesempatan dan diwujudkan dalam tiga pilar yaitu people, profit dan planet.

\section{Konsep One Village One Product}

Konsep One Village One Product (OVOP) merupakan pembangunan ekonomi yang bermula dari Jepang tahun 1970an diperkenalkan oleh Dr. Morihiko Hiramatsu, Gubernur Oita Prefecture. Adapun tujuan pengembangan Program One Village One Product secara umum antara lain: Menarik kembali masyarakat yang terlanjur berpindah dari pedesaan ke kota,Mengembangkan budaya dan industri pedesaan, Memberikan nilai tambah bagi aktivitas masyarakat yang sudah dilakukan secara turun-temurun, Dengan adanya nilai tambah bagi aktivitas masyarakat akan mengangkat derajat masyarakat pedesaan, Pengembangan industri pedesaan mencapai pasar internasional.

Program OVOP di Indonesia merupakan program berbasis community development. (Pratiwi, Pascarani, \& Winaya, 2016) mengemukakan tiga prinsip dasar dalam pengembangan OVOP: Lokal tapi global, Pengembangan OVOP bertujuan untuk mengembangkan produk yang dihasilkan masyarakat lokal. Artinya komoditas yang bersifat lokal bisa menjadi komoditas yang internasional, Kemandirian dan kreativitas, Potensi produk yang dikembangkan adalah produk disetiap daerah. Pada umumnya, Program OVOP disadarkan berdasarkan inisiatif masyarakat lokal, semangat kemandirian dan kreatifitas masyarakat untuk menjadi potensi regional, Pengembangan sumber daya manusia

Program OVOP memiliki prinsip untuk memacu sumber daya manusia dilingkungan daerahnya agar mampu kreatif dan inovatif.

\section{III.METODE}

Penelitian ini akan dilakukan di Desa Wisata Pelaga, Kecamatan Petang, Badung, Bali. Dipilihnya Desa Pelaga sebagai lokasi penelitian karena desa ini dikenal sebagai desa pertanian yang didukung oleh potensi wisata agro yang menarik dan ekologinya yang utuh. Jenis penelitian ini adalah penelitian survei dengan menerapkan teknik sampling jenuh suatu teknik 
penentuan sampel jika semua anggota populasi digunakan sebagai sampel. Sampel pada penelitian ini adalah petani asparagus sejumlah 122 orang.

Jenis data yang digunakan pada penelitian ini adalah data kuantitatif berupa hasil kuesioner yang merupakan jawaban responden yang diukur menggunakan skala pengukuran semantic differential, serta data kualitatif yang diperoleh dari hasil wawancara dengan responden. Peneliti melakukan pencatatan, penganalisisan dan penarikan kesimpulan terhadap penerapan konsep triple bottom line accounting pada kelompok usaha tani asparagus di Desa Wisata Pelaga dan pengurus Koperasi Tani Mertanadi. Teknik pengumpulan data yang digunakan meliputi kuesioner, wawancara, dan observasi non partisipan.

Indikator yang akan diamati dan diukur pada penelitian ini adalah konsep Triple Bottom Line Accounting yang terdiri dari planet, people, dan profit berpedoman pada kuesioner yang dimodifikasi dari Hackston dan Milne (1999) dalam (Sembiring, 2005).

Penelitian ini menggunakan teknik analisis statistik deskriptif dan teknik analisis deskriptif kualitatif. Teknik analisis statistik deskriptif digunakan untuk memberikan informasi mengenai karakteristik variabel penelitian dan menjelaskan skala jawaban responden terkait variabel yang diukur. Sementara teknik deskriptif kualitatif digunakan untuk mendeskripsikan lebih rinci terkait penerapan dan dampak penerapan komponen 3P yang merupakan bagian dari konsep Triple Bottom Line Accounting pada kelompok usaha tani asparagus di Desa Wisata Pelaga.

\section{IV.HASIL PENELITIAN DAN PEMBAHASAN}

\section{Analisis Statistik Deskriptif}

Statistik deskriptif memberi gambaran

Tabel 2

Descriptive Statistics

\begin{tabular}{cccccc}
\hline & N & Minimum & Maximum & Mean & Std. Deviation \\
\hline planet & 122 & 28 & 34 & 31,18 & 2,163 \\
people & 122 & 48 & 64 & 55,57 & 3,950 \\
profit & 122 & 37 & 49 & 43,23 & 2,699 \\
Valid N (listwise) & 122 & & & & \\
\hline
\end{tabular}

mengenai setiap variabel yang menunjukkan nilai rata-rata (mean), standar deviasi, nilai maksimum, dan nilai minimum. Nilai rata-rata pilar planet adalah sebesar 31,18. Nilai maksimum pilar planet sebesar 34 sedangkan nilai minimumnya sebesar 28. Nilai deviasi standar menunjukkan rata-rata penyimpangan data planet sebesar 2,163 dari nilai yang diharapkan.

Nilai rata-rata pilar people adalah sebesar 55,57. Nilai maksimum pilar people sebesar 64 sedangkan nilai minimumnya sebesar 48 . Nilai deviasi standar menunjukkan rata-rata penyimpangan data people sebesar 3,950 dari nilai yang diharapkan.

Nilai rata-rata pilar profit adalah sebesar 43,23. Nilai maksimum pilar profit sebesar 49 sedangkan nilai minimumnya sebesar 37 . Nilai deviasi standar menunjukkan rata-rata penyimpangan data profit sebesar 2,699 dari nilai yang diharapkan.

\section{Analisis Deskriptif Kualitatif}

Pilar Planet

Pilar planet menggambarkan tentang kepedulian sebuah aktivitas bisnis terhadap lingkungan sekitar, seperti misalnya aktivitas operasional usaha yang ramah lingkungan dan rendah polusi. Terkait pengendalian polusi pada budidaya asparagus di Desa Pelaga telah dilakukan dengan cukup baik, meskipun masih terdapat pemanfaatan pupuk kimia, namun mayoritas para petani asparagus di Desa Pelaga tetap menggunakan pupuk organik seperti pupuk kandang dalam proses pembudidayaan sayuran asparagus, sehingga dapat disimpulkan bahwa aktivitas usaha ini tidak berdampak negatif terhadap alam lingkungan. Asparagus merupakan maskot dari Kabupaten Badung. Kualitas asparagus di Desa Pelaga memiliki predikat asparagus dengan kualitas terbaik se Asia, dimana sertifikat tersebut disimpan di Dinas Pertanian Kabupaten Badung.

Produk asparagus yang dihasilkan di Desa Pelaga memiliki tingkatannya masing-masing yang terdiri dari Grade Super, Grade A, Grade B, 
dan Grade C. Tingkatan kualitas asparagus ditentukan oleh tingkat kehijauan serta ukuran dari sayuran asparagus. Sayuran asparagus dengan ukuran lebih dari $10 \mathrm{~cm}$ masuk dalam spesifikasi Grade Super, ukuran 8 hingga $10 \mathrm{~cm}$ masuk dalam kategori Grade A, ukuran 6 hingga $7 \mathrm{~cm}$ masuk dalam kategori Grade $B$, dan ukuran kurang dari $6 \mathrm{~cm}$ masuk dalam kategori Grade $C$. Untuk produk dengan kualitas kurang dari yang disebutkan diatas akan masuk dalam kategori KW. Sayuran asparagus yang memiliki grade akan langsung dipasarkan ke supermarket, sementara sayuran dengan kategori KW akan dipasarkan ke restoran. Meskipun begitu, sayuran asparagus dengan kategori $\mathrm{KW}$ tidak memiliki rasa yang berbeda. Perbedaannya hanya terletak dari ukurannya saja. Sejauh ini hampir seluruh bagian dari sayuran asparagus mampu dimanfaatkan untuk menghasilkan rupiah. Sisasisa potongan kecil atau ampas dari sayuran ini pun mampu diolah menjadi sesuatu yang bernilai ekonomis. Para petani asparagus termasuk masyarakat setempat telah berupaya untuk mendaur ulang sisa-sisa sayuran asparagus. Hasilnya adalah sisa-sisa potongan sayuran asparagus dapat diolah menjadi kudapan seperti pudding, lumpia, ice cream, hingga soup. Hasil ini bahkan telah dipamerkan pada Festival Pertanian Asparagus. Namun permasalahan yang masih dihadapi para petani yakni kesulitan dalam menentukan biaya volume laba serta komposisi dari hasil akhir pemanfaatan sisa asparagus. Masalah lainnya yang muncul yaitu permintaan terkait soup yang tidak berkelanjutan sehingga menyebabkan usaha pengolahan sisa sayuran asparagus kerap tersendat. Ketika permintaan akan soup asparagus surut, sisa-sisa potongan asparagus ini terpaksa harus dibuang dan menjadi pakan ternak. Hal ini sangat disayangkan dikarenakan sayuran asparagus memiliki potensi serta nilai jual yang sangat tinggi, sehingga diharapkan seluruh bagian dari sayuran asparagus mampu dimanfaatkan secara berkesinambungan.

Terkait dengan pemanfaatan lokasi budidaya asparagus sebagai sarana rekreasi maupun edukasi belum difokuskan ke arah sana oleh pihak desa. Sejauh ini pihak desa masih berfokus pada aktivitas bisnis seperti jual beli sayuran asparagus. Namun apabila tertarik lebih jauh, masyarakat luar khususnya pelajar diperbolehkan untuk mengetahui dan mempelajari budidaya asparagus dengan menyertakan surat pengantar dari instansti terkait.

Pilar People
Pilar people berkaitan dengan bentuk kepedulian perusahaan terhadap sumber daya manusia yakni tenaga kerja serta masyarakat sekitar. Seluruh masyarakat di Desa Pelaga memiliki kesempatan yang sama apabila tertarik menjadi petani asparagus, dengan syarat memiliki lahan sebagai media tanam. Namun belakangan dikarenakan harga bibit asparagus yang tergolong mahal, serta proses memperolehnya yang cukup sulit yakni harus melakukan pemesanan dari luar negeri (import), maka hanya petani yang bersedia berkomitmen yang diizinkan untuk menjadi petani asparagus. Terdapat mekanisme reward and punishment terhadap kinerja petani asparagus. Petani diharuskan menjual hasil panennya kepada pihak Koperasi Tani Mertanadi sebagai perantara atau penyalur hasil panen ke pasar swalayan serta restoran. Khusus bagi petani yang bertindak curang akan menerima punishment seperti dikeluarkan dari keanggotaan koperasi. Sementara bagi petani yang memiliki kinerja baik dengan penjualan tertinggi akan memperoleh reward berupa bonus dalam bentuk uang tunai ataupun keperluan bertani seperti pupuk dan keperluan lainnya.

Terdapat pengungkapan jumlah tenaga kerja serta hierarki managerial pada aktivitas bisnis ini. Jumlah petani asparagus di Desa Pelaga sejumlah 122 orang petani, sementara jumlah karyawan pada Koperasi Tani Mertanadi adalah berjumlah 16 orang. Aktivitas pembudidayaan asparagus ini juga memanfaatkan tenaga kerja wanita baik sebagai petani asparagus maupun sebagai karyawan di Koperasi Tani Mertanadi. Namun belum ada pemanfaatan orang cacat sebagai petani asparagus maupun pengurus koperasi. Secara umum para petani asparagus di Desa Pelaga melaksanakan aktivitas pertanian yang ramah lingkungan. Hal tersebut tercermin dari penggunaan pupuk yang mayoritas merupakan pupuk organik sehingga memiliki risiko kerja yang minim dikarenakan tidak menyebabkan polusi maupun iritasi bagi para petani asparagus.

Program OVOP di Desa Pelaga merupakan kerjasama antara dua negara yakni Indonesia yang dalam hal ini Kementrian Koperasi dan UKM Republik Indonesia dengan ICDF (International Cooperation and Development Fund) Taiwan. Pada tahapan awal yakni pada tahun 2010, para petani di Desa Pelaga diberikan pembinaan dan pelatihan khusus pertanian terkait cara membudidayakan sayuran asparagus dengan didampingi oleh relawan Taiwan Technical Mission (TTM) yang merupakan bagian dari 
ICDF (International Cooperation and Development Fund) Taiwan. Proses pelatihan dan pendampingan ini dilaksanakan dari tahun 2010 hingga 2015. Setelah kiranya dianggap mandiri, pihak ICDF Taiwan memberikan kewenangan tanggungjawab budidaya asparagus sebagai potensi sayuran hortikultura kepada para petani di Desa Pelaga serta pihak desa dan Pemerintah Kabupaten Badung. Namun apabila seiring waktu pihak pengelola mengalami permasalahan terkait budidaya asparagus, pihak ICDF Taiwan tetap bersedia memberikan konsultasi pemecahan masalah.

\section{Pilar Profit}

Pilar profit berkaitan dengan kemampuan sebuah aktivitas bisnis untuk menghasilkan keuntungan. Melalui kegiatan One Village One Product (OVOP) yang tercermin pada budidaya sayuran asparagus dapat disimpulkan bahwa pertanian asparagus yang dikembangkan di Desa Pelaga sejak tahun 2010 telah mampu meningkatkan taraf hidup petani serta menopang perekonomian petani di Desa Pelaga. Hal tersebut dapat dilihat dari harga asparagus dimulai dari harga Rp35.000 hingga Rp50.000 tergantung dari kualitas asparagus tersebut. Dalam sehari para petani mampu menghasilkan pendapatan sekitar Rp500.000 hingga Rp1.000.000 tergantung luas lahan yang dimiliki.

Pemerintah setempat sadar bahwa asparagus merupakan produk sayuran unggulan hortikultura yang memiliki potensi ekonomi besar bagi masyarakat khususnya di Desa Pelaga. Hal tersebut mendorong pihak pemerintah dalam hal ini Pemerintah Kabupaten Badung untuk membantu mempromosikan sayuran asparagus yang dihasilkan di Desa Pelaga melalui media cetak ataupun elektronik. Contohnya adalah promosi melalui media baliho ataupun media sosial terkait Festival Asparagus yang secara rutin diselenggarakan dengan tujuan mensosialisasikan kepada masyarakat luas mengenai keberadaan asparagus di Desa Pelaga. Selain itu, Pemerintah Kabupaten Badung juga memberikan bantuan berupa dana maupun sarana dan prasarana terkait budidaya sayuran asparagus ini. Terkait dengan akses pemasaran, sayuran asparagus khususnya dari Desa Pelaga telah dipasarkan di pasar swalayan, hotel-hotel di Bali bahkan hingga ke Jakarta dan Bogor berkat bantuan dari pihak ICDF Taiwan. Selain proses pemasaran produk sayuran asparagus, pihak ICDF Taiwan banyak berjasa termasuk pemberian bantuan bibit sayuran asparagus.

Berbicara tentang mekanisme pembagian keuntungan dapat dijelaskan sebagai berikut. Para petani melakukan penjualan hasil panen kepada Koperasi Tani Mertanadi dengan harga jual sesuai dengan kesepakatan dan harga pasar. Meskipun terjadi penurunan harga pasar, petani akan tetap memperoleh hasil penjualan sesuai dengan kesepakatan. Pasokan sayuran asparagus dari para petani ini akan dipasarkan oleh pihak koperasi ke hotel, restoran, supermarket serta dikirim keluar bali seperti Jakarta dan Bogor. Keuntungan hasil penjualan akan dibagikan pada akhir tahun ketika diselengkarakan Rapat Anggota Tahunan Koperasi.

\section{SIMPULAN}

Penjabaran ketiga pilar dari konsep Triple Bottom Line Accounting yakni planet, people, dan profit telah dijabarkan menjadi poin-poin pernyataan pada instrumen kuesioner. berdasarkan pembahasan hasil yang telah dipaparkan diatas baik secara kuantitatif maupun kualitatif, dapat disimpulkan bahwa penerapan konsep triple bottom line accounting di desa wisata pelaga (studi kasus pada kelompok usaha tani asparagus) secara umum dapat disimpulkan telah berjalan dengan baik. Meskipun masih terdapat beberapa kekurangan seperti para petani yang mengalami kesulitan dalam menentukan biaya volume laba serta komposisi dari hasil akhir pemanfaatan sisa asparagus. Serta masalah lainnya seperti permintaan terkait pengolahan sisa sayuran asparagus yang kerap tersendat, sehingga terkadang sisa-sisa potongan asparagus ini terpaksa harus dibuang dan menjadi pakan ternak. Hal ini sangat disayangkan dikarenakan sayuran asparagus memiliki potensi serta nilai jual yang sangat tinggi, sehingga diharapkan seluruh bagian dari sayuran asparagus mampu dimanfaatkan secara berkesinambungan. Peneliti selanjutnya disarankan melakukan penelitian terkait penentuan biaya volume laba serta komposisi dari hasil akhir pemanfaatan sisa asparagus. Alternatif lainnya yakni penelitian selanjutnya dapat menganalisis pangsa pasar yang dapat berkesinambungan terkait pemanfaatan sisa sayuran asparagus.

\section{DAFTAR PUSTAKA}

Elkington, J. (1998). ACCOUNTING FOR THE TRIPLE BOTTOM LINE. Measuring Business Excellence, 2 (3), 18-22. Retrieved from https:// www.emerald.com/insight/content/doi/10.1108/ 
$\mathrm{eb025539/full/html}$

Foran, B., Lenzen, M., Dey, C., \& Bilek, M. (2005). Integrating sustainable chain management with triple bottom line accounting. Ecological Economics, 52 (2), 143-157. Retrieved from https://ideas.repec.org/ a/eee/ecolec/v52y2005i2p143-157.html

Hijauku. (2019). Ekonomi Hijau, Ekonomi Berkeadilan Sosial. Retrieved from http:// www.hijauku.com/2012/01/01/ekonomi-hijauekonomi-berkeadilan-sosial

Ilma, A. F. N. (2014). Blue Economy: Kesimbangan Perspektif Ekonomi dan Lingkungan. Jurnal Ilmu Ekonomi Dan Pembangunan, 14(1). Retrieved from https://jurnal.uns.ac.id/jiep/article/view/2112

Lako, A. (2015). Green Economy: Menghijaukan Ekonomi, Bisnis, \& Akuntansi. Jakarta: Erlangga.

Nasional kompas. (2017). alasan para petani kendeng rela mencor kaki di depan istana negara. Retrieved from https://nasional.kompas.com/ $\mathrm{read} / 2017 / 03 / 19 / 20014381 /$

alasan.para.petani.kendeng.rela.mencor.kaki.di.depan .istana.negara

Pratiwi, K. R. I., Pascarani, N. N. D., \& Winaya, I. K. (2016). Evaluasi Pelaksanaan Program One Village One Product (OVOP) dalam Pemberdayaan Masyarakat di Desa Pelaga, Kecamatan Petang, Kabupaten Badung. Citizen Charter, 1(1), 1-9. Retrieved from https://ojs.unud.ac.id/index.php/ citizen/article/view/23401

S, M. J., \& Arifah, D. A. (2006). Pengaruh Dorongan Manajemen Lingkungan, Manajemen Lingkungan Proaktif Dan Kinerja Lingkungan Terhadap Public Environmental Reporting. Simposium Nasional Akuntansi 9 Padang. Retrieved from https:// smartaccounting.files. wordpress.com/2011/03/kakpm27.pdf

Sembiring, E. R. (2005). Karakteristik Perusahaan Dan Pengungkapan Tanggung Jawab Sosial: Study Empiris Pada Perusahaan Yang Tercatat Di Bursa Efek Jakarta. SNA VIII Solo. Retrieved from http:// mahasiswa.dinus.ac.id/docs/skripsi/jurnal/12943.pdf

Swa.co.id. (2019). Triple Bottom Line Lebih Dari Sekadar Profit. Retrieved from https://swa.co.id/swa/myarticle/triple-bottom-line-lebih-dari-sekadar-profit

Wahyudin, D. (2016). Strategi Konsep Ekonomi Hijausebagaisuistainable Development Goalsdi Indonesia. Prosiding Seminar STIAMI, 3(1), 34-45. Retrieved from https://docplayer.info/31258464Strategi-konsep-ekonomi-hijau-sebagai-suistainabledevelopment-goals-di-indonesia.html

Wilson, J. P. (2015). The triple bottom line: Undertaking an economic, social, and environmental retail sustainability strategy. International Journal of Retail \& Distribution Management, 43(4), 432-447. Retrieved from https://www.emerald.com/insight/ content/doi/10.1108/IJRDM-11-2013-0210/full/ html?fullSc=1

Peraturan Bupati Badung Nomor 47 Tahun 2010 tentang Penetapan Kawasan Desa Wisata di Kabupaten Badung.

Peraturan Gubernur Nomor 97 Tahun 2018 tentang Pembatasan Timbulan Sampah Plastik Sekali Pakai. 